\title{
A PRELIMINARY STRUCTURAL SURVEY OF HERITAGE TIMBER LOG HOUSES IN TONSBERG, NORWAY
}

\author{
AMIRHOSEIN SHABANI ${ }^{1 *}$, HAIDAR HOSAMO ${ }^{1}$, \\ VAGELIS PLEVRIS ${ }^{2,1}$ AND MAHDI KIOUMARSI ${ }^{1}$ \\ ${ }^{1}$ Department of Civil Engineering and Energy Technology \\ OsloMet-Oslo Metropolitan University \\ Pilestredet 35, 0166 Oslo, Norway \\ email: \{amirhose, haidarho, mahdik\}@oslomet.no, www.oslomet.no \\ (*corresponding author) \\ ${ }^{2}$ Department of Civil and Architectural Engineering \\ Qatar University \\ P.O. Box: 2713, Doha, Qatar \\ email: vplevris@qu.edu.qa, web page: www.qu.edu.qa
}

Keywords: Preliminary Survey, Heritage Timber Structures, Log House, 3D Laser Scanner, Visual Inspection, Environmental Attack, Vulnerability Assessment

\begin{abstract}
The formulation of a multi-hazard loss model for a given structure is not only of interest for predicting the economic impact of future damage but it can also be of importance for risk mitigation. A methodology that can assess the vulnerability of the built environment is a significant component of a loss model. The multi-risk vulnerability of heritage buildings necessitates greater knowledge about the history of their construction, including aspects relating to preserving them as assets. Timber as an organic material is more susceptible to decay and the structural assessment of timber buildings is essential for their preservation. A preliminary survey as a basis for multi-risk vulnerability assessment of such buildings is essential. In this step of the process, the history of the building is investigated, as well as any intervention to it during its lifetime. A damage inspection of structural elements conducted by experts is an essential part of the second step. After this, the configuration of the building, including height, plan view and connection details should be documented. After the preliminary survey of the building, detailed methods are employed to gather further information about the structure's behaviour under different risk scenarios. In this paper, heritage timber buildings in Tønsberg, Norway have been selected as case studies for multi-risk vulnerability assessments. The preliminary survey has been conducted by a team of experts and useful data have been recorded and explained. $3 D$ laser scanners have been used in the survey in place of traditional $2 D$ methods to obtain a more detailed and accurate $3 D$ representation of the buildings.
\end{abstract}

\section{INTRODUCTION}

Heritage structures are culturally, economically and socially important to preserve for the nations around the world. Timber as the oldest organic construction material is widely used in 
heritage structures. Timber is more susceptible to environmental risks than masonry bricks or stone, and its behaviour is quite complex. The preservation of heritage structures and the preservation of craftsmanship techniques represent two sides of the same coin [1]. For other types of materials, modern preservation techniques can potentially be used, but in the case of timber, traditional techniques are recommended because of the susceptibility of timber to decay and the necessity of replacing members at given intervals $[2,3]$.

A methodology for the structural vulnerability assessment of heritage timber buildings is proposed by Shabani et al. (2020) [4] in the context of HYPERION project and as the first and principal step of the methodology, a preliminary survey should be conducted by experts. In this step, risk effects that can be seen by the human eye are documented and the structural system, including connections or roof structure systems, is evaluated. Moreover, a geometric survey should be carried out to document the configuration of the building, either in the form of traditional 2D drawings or modern 3D BIM files. Potential risks based on the codes, previous disaster records or visual inspections must be estimated during this stage [4, 5].

Log houses are one of the ancient timber structural systems. In a log house structural system, the horizontal timber logs are laid on top of each other and the stability of the structure is provided by the corner joints where the wall planes interlock, as illustrated in Figure 1. The log house system is used in northern European countries and in the central Alpine region, which also extends into several eastern European countries. The technique can also be seen in Japan,
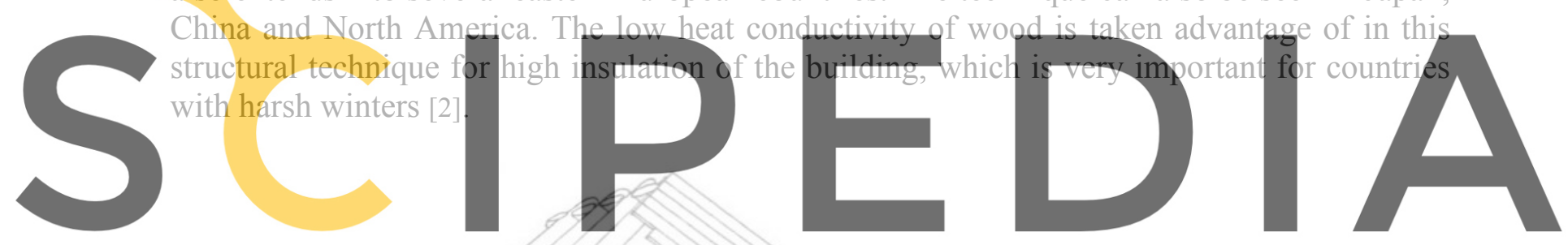

Register for free at https//www.scipedia.com to download the version without the watermark

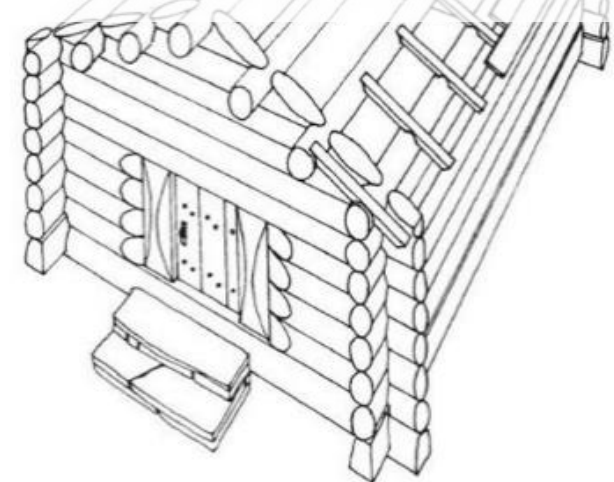

(a)

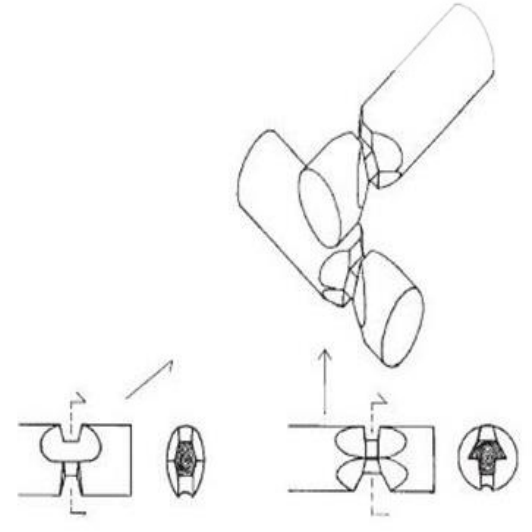

(b)

Figure 1: (a) Typical Log house schematic view, (b) Typical log house corner connection detail [2]

Laser scanners are machines that use a controlled deflection of laser beams for distance measurements. By taking a distance measurement in every direction, the scanner rapidly 
captures the surface shape of objects, buildings and landscapes without representing any risk of damaging the structure. Terrestrial laser scanning has been utilised to perform stability analyses of masonry arches by transforming point clouds into metric images [6] of masonry arches in a heritage masonry Bridge. This was done by combining a set of point clouds with static methods [6-8]. Bethlehem's Nativity church has also been scanned using a laser scanner, and a 3D model was prepared for use in studies under several types of loads [9]. In addition, a new method was developed to simulate the timber roofs of the Vienna Imperial Palace using a laser scanner [10]. $3 \mathrm{D}$ documentation is therefore a good tool for informing risk management processes relating to heritage structures [11].

The case studies in this paper are from Tønsberg, which is a Norwegian town and municipality in the Vestfold Region. It is located south-southwest of Oslo on the western coast of the Oslo fjord. According to the sagas, Tønsberg was founded in the Viking period at the end of the $9^{\text {th }}$ century, yet no archaeological discoveries have confirmed these sources. Today it is believed that the town was founded in the $10^{\text {th }}$ century, which still makes Tonsberg among the oldest cities in Norway [12].

Natural conditions such as good available farmland, a safe port and possibilities for fortifications and defence laid the foundations for the city's development. Tønsberg is dominated by a steep-sided cliff (Slottsfjellet). Urban structures comprising long, narrow estates divided by streets and narrow alleys were established in the $12^{\text {th }}$ century at the foot of the cliff and along the harbour. The settlement consisted mainly of one or two storey wooden

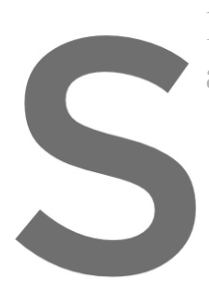
log houses. The locations of the are shown in Figure 2
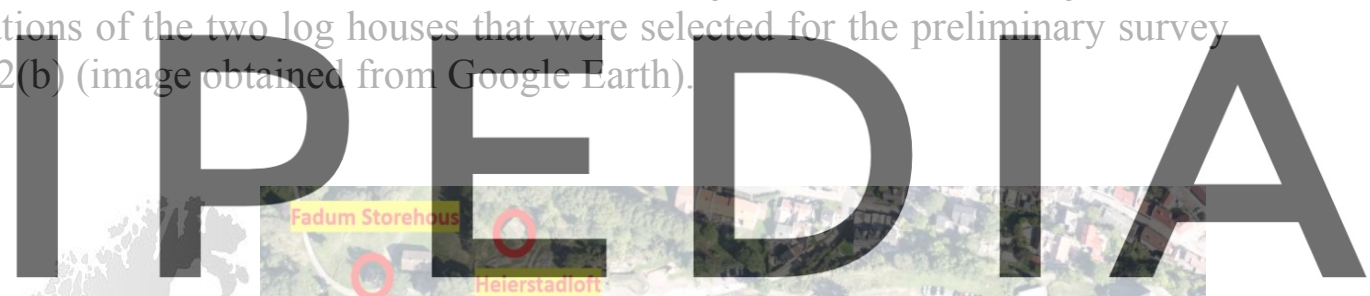

Register for free at https//www.scipedia.com to download the version without the watermark

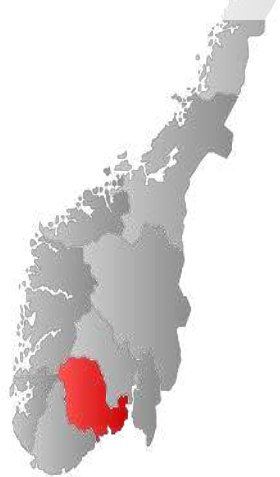

(a)

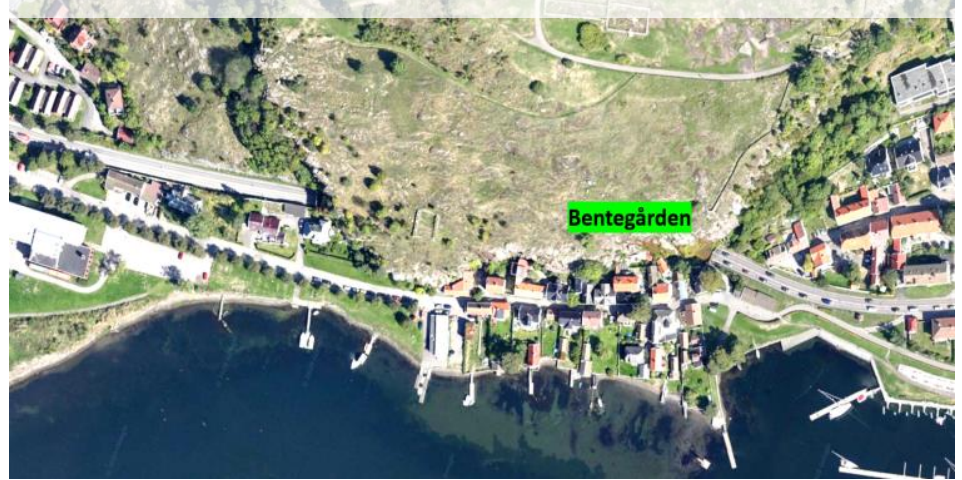

(b)

Figure 2: (a) The location of Tønsberg in southern Norway, (b) The location of the two case studies 
The preliminary survey of the two historical log houses was carried out from a structural perspective by evaluating the structural system, history of the buildings including interventions, damage documentation, potential future risks and 3D architectural documentation of the buildings. Based on the possible future risks, 3D laser scanners were employed to provide accurate architectural documentation for two of the case studies which 3D BIM drawings have been provided. 3D drawing can be converted to finite element models for future numerical analysis. Compared with conventional geodetic methods (traditional single-point measurements), the 3D laser scanning technology exhibits strong advantages. Its data acquisition has the advantages of high efficiency, high precision, non-contact measurement, high data resolution and fast speed.

\section{CASE STUDIES}

A preliminary survey is an essential part of conducting a vulnerability assessment of heritage structures. The two selected log houses in Tønsberg were investigated from a structural perspective, as presented in the following sections.

\subsection{Heierstad Loft}

The Heierstad Loft is a store house originally located on the farm Heierstad, $50 \mathrm{~km}$ north of Tønsberg. The whole house was moved to the Slottsfjell Museum in Tønsberg, where it was restored in 1957. The lower floor is in its original state and has been dated to 1407 by

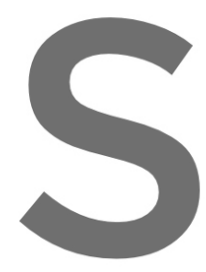
dendrochronology, whil The building has a rectangular p metres. It is built (logg construction. The roofin birch bark and turf. The exterio
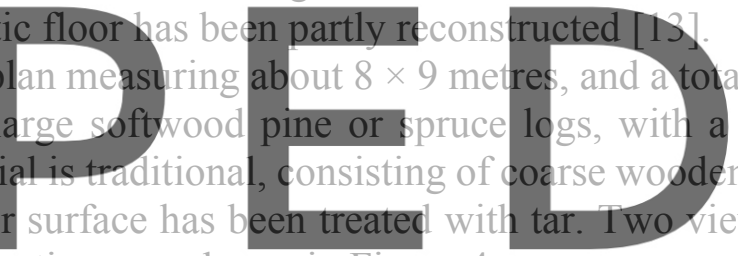
and details of the roof and connections are shown in Figure 4.
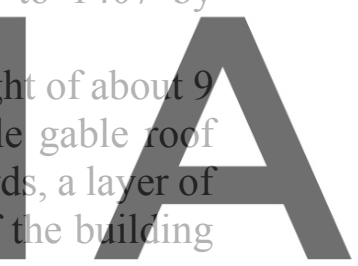

Register for free at https//www.scipedia.com to download the version without the watermark
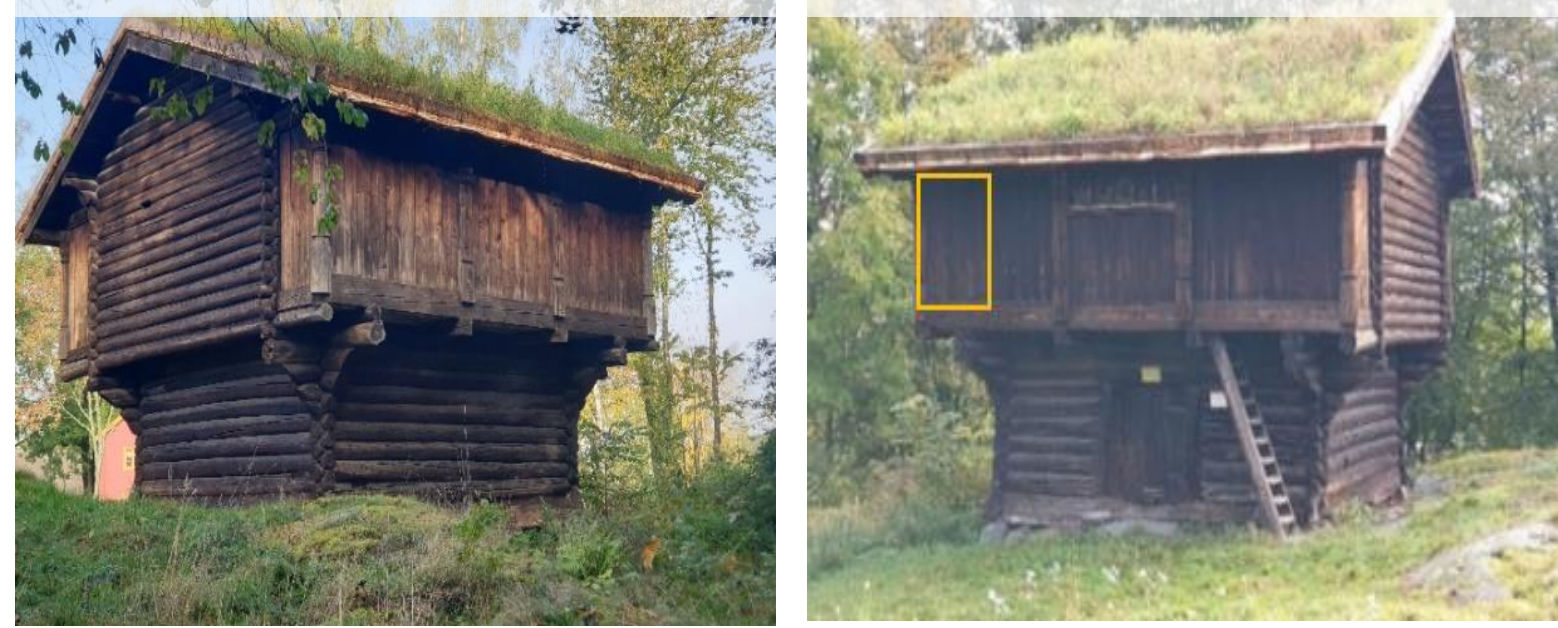

Figure 3: Heierstad Loft case study from two different views 
As it is illustrated in Figure 4(b), two supporting beams are employed, and the main beams are laid orthogonally on them. All the roof system's timber logs of the second floor are laid orthogonally on the main beams. However, due to the lower dead and live loads on the second roof compared to the first roof, the supporting beams have not been utilised and the roof system's logs are laid on the main beams as it is shown in Figure 4(c).

The area of the second floor is more than the first floor. As it is illustrated in Figure 4(d), this issue can lead to overturning of the building and in order to tackle with this risk, the main beams of the first floor are continued and as it is shown in Figure 4(e), upper logs are longer in the corner joints.

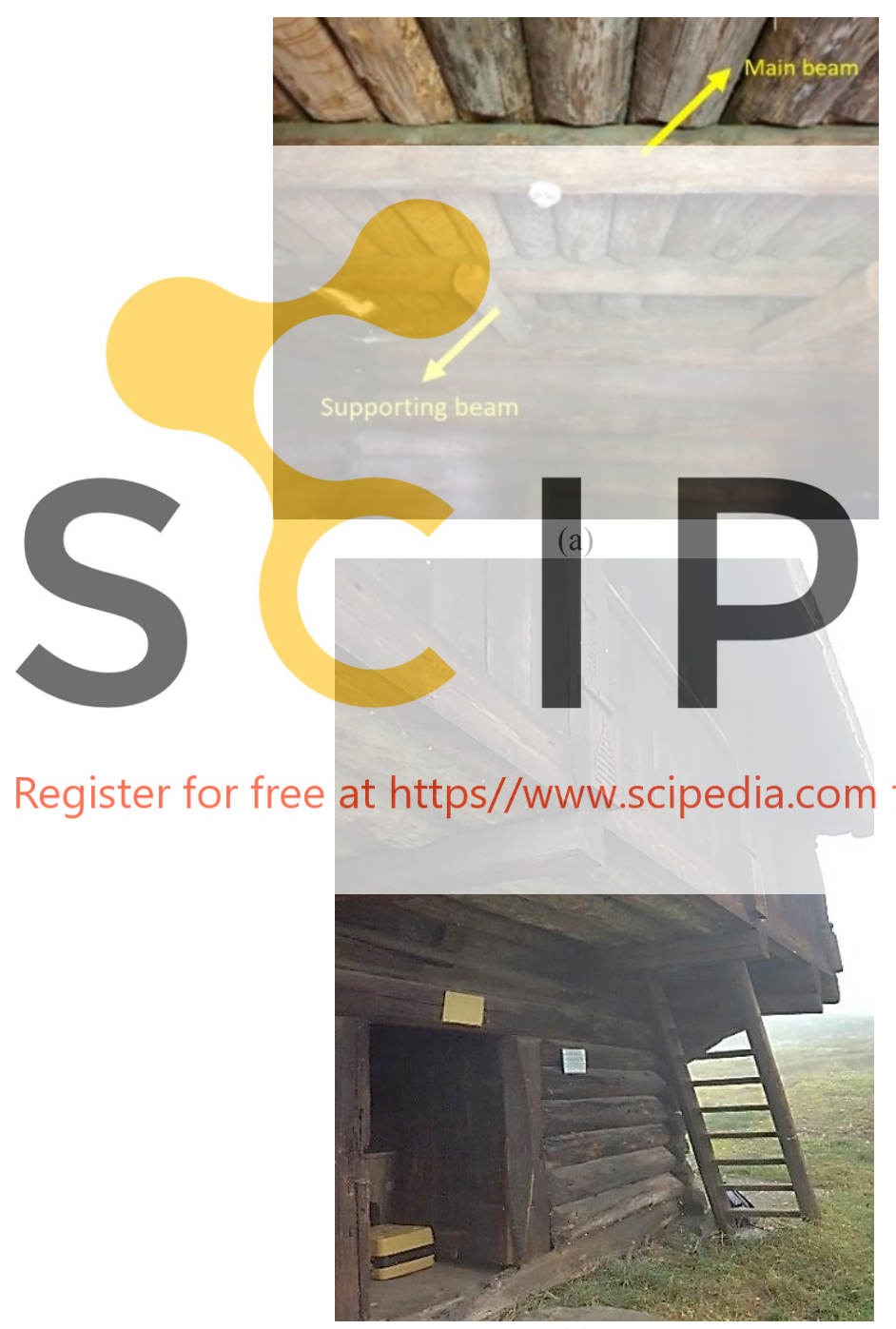

(c)

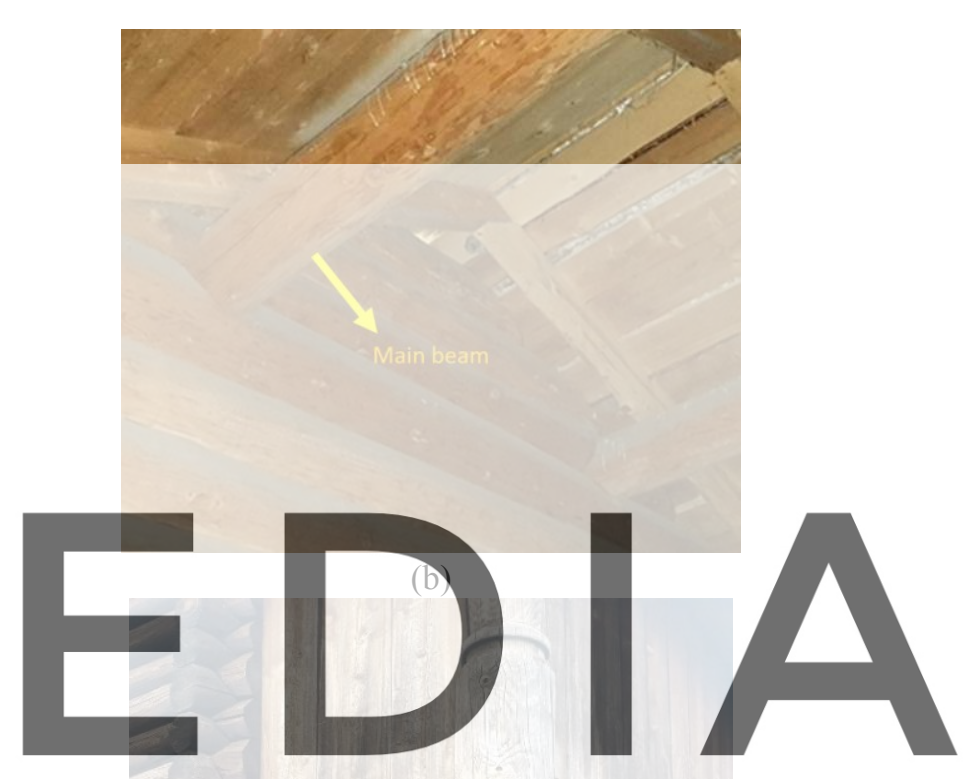

to download the version without the watermark

Figure 4: (a) Connection details inside the building for the $1^{\text {st }}$ and (b) $2^{\text {nd }}$ storey roof, (c) structural details of the $2^{\text {nd }}$ floor system, (d) connection detail of the corner joint 
The building is in good condition in general, but it requires continuous maintenance. The most relevant degradation factors are general weathering, high humidity levels, biological decay (see Figure 5) and foundation settlement.

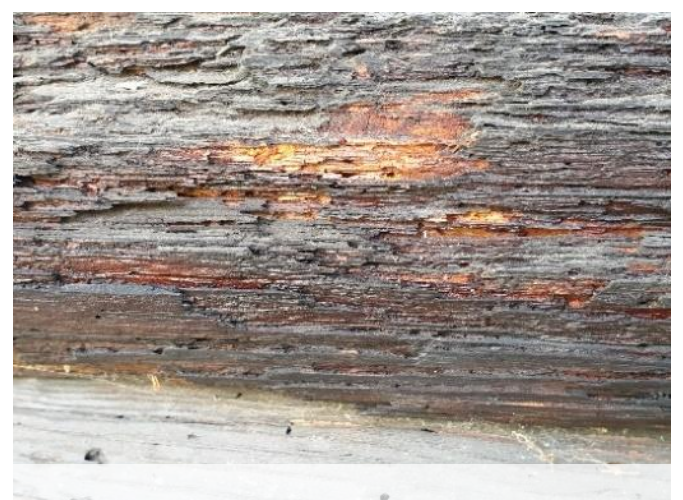

(a)

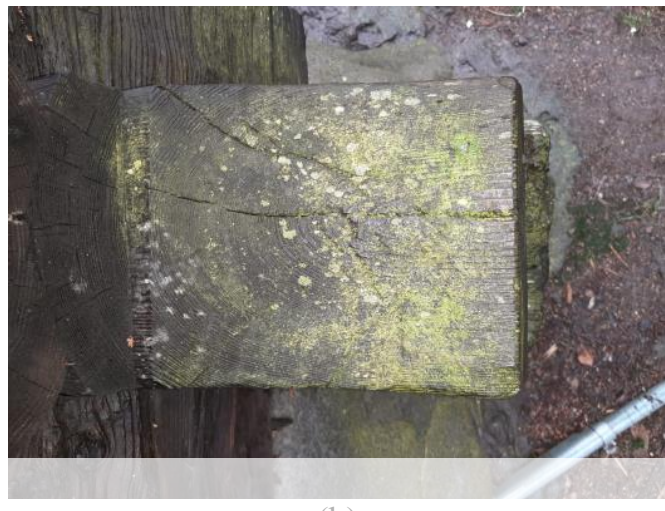

(b)

Figure 5: Biological defects in Heierstad Loft

\subsection{Fadum Storehouse}

The Fadum Storehouse is a log house covered by a coat of insulation because of its original use as a storehouse. The structure dates back as far as the 1750s, and it is constructed with small timber columns on a stone foundation. The strueture has two stories with dimensions $6.40 * 5.30$ for each of them. The material properties and the risks are the same as those of previous building [14

The building and its structural detalls are shown in Figure 6. As it is jllustrate 6(d), the floor system is laid on the short timber columns which are on stone found main surrounding beams of the floor are simply connected to the columns without any

Register for free at Rttps/NWww.scipedia.com to download the version without the watermark

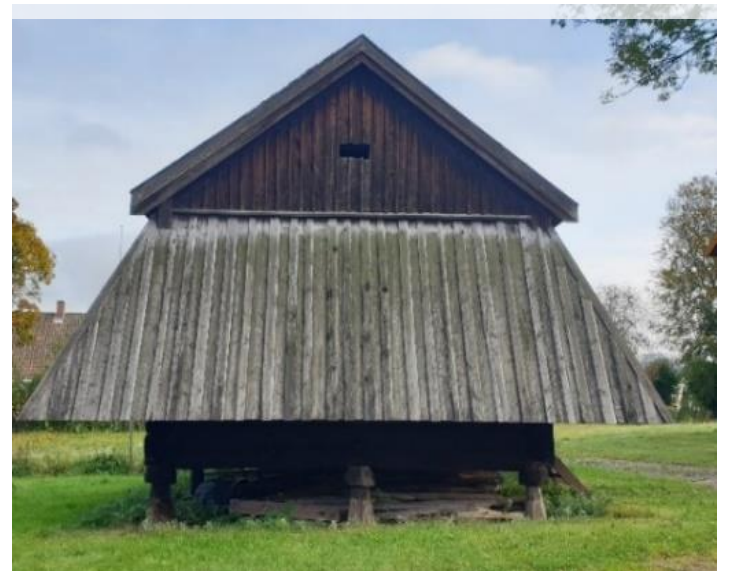

(a)

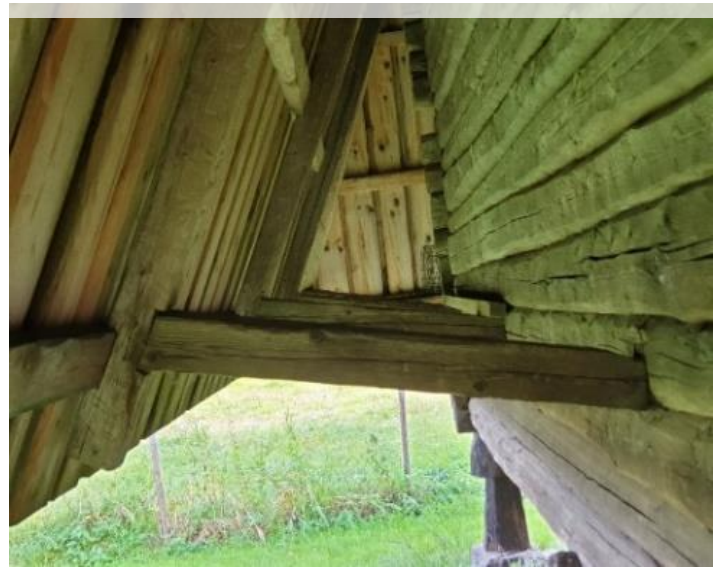

(b) 


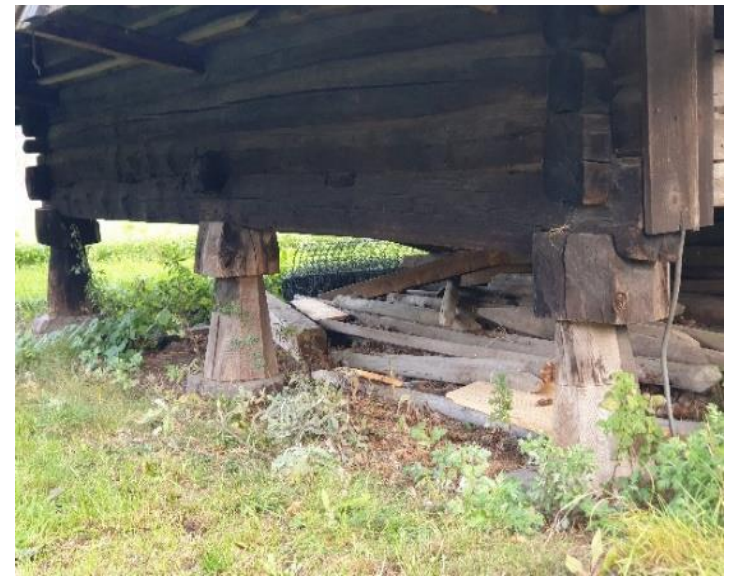

(c)

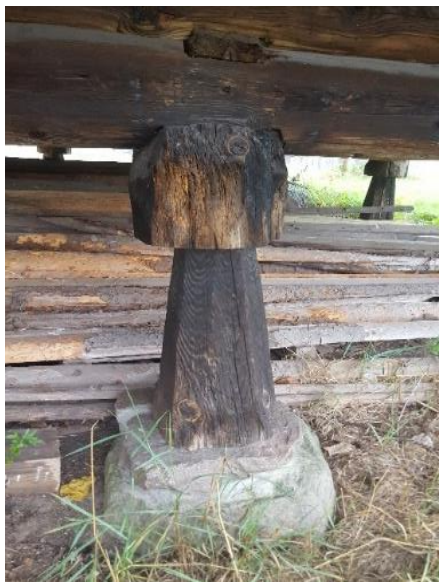

(d)

Figure 6: (a) Fadum Storehouse view, (b) Structural detail inside the coating, (c) Timber short columns under the building, (d) detail of the simply connected timber column

This building is generally in good condition but some deflection in main surrounding beams

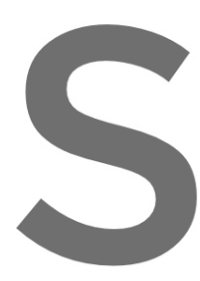
$\operatorname{logs}$ and on the coati

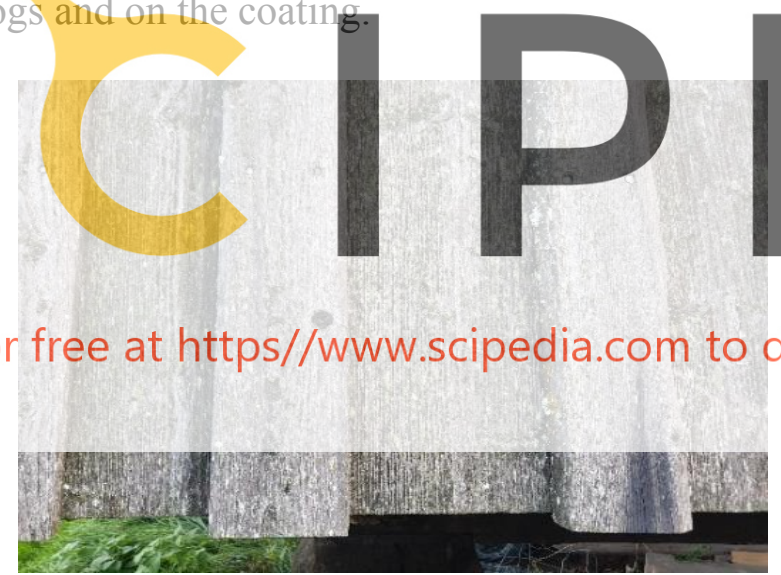

(a)
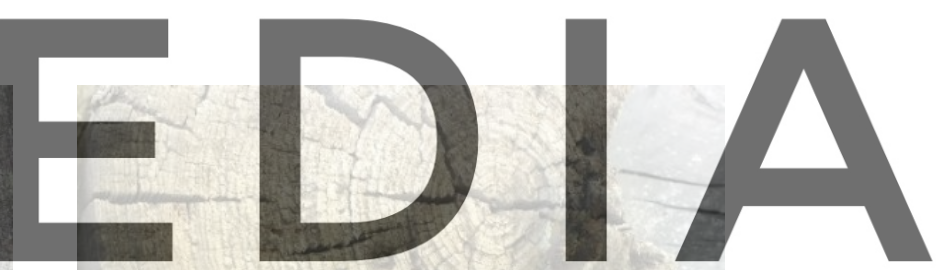

Register for free at https//www.scipedia.com to download the version without the watermark

Figure 7: (a) Lichen attack to the coating, (b) Insect attack on the timber logs

\section{3D DOCUMENTATION}

Analysing 2D images can be very useful in many machine vision applications, but it is sometimes more helpful or even necessary to create a 3D image or representation of an object, such as in robotics, logistics applications or autonomous vehicles applications. Today, various imaging techniques can provide 3D information for machine vision purposes. Scanning techniques use a projected line of light onto a surface. [15].

Fadum Storehouse and Heirestad Loft structures are chosen for performing 3D laser scanning which can be easily converted to finite element models for further studies. A total of eighteen scans, twelve exterior and six interiors, were carried out for the Fadum Storehouse and 
Heierstad Loft structures investigated in the present study. The structures have an easily accessible indoor environment and design characteristics including diversity and a number of different building components.

The equipment used was a Topcon 2000 3D laser scanner, which is able to scan the entire building. The laser scanner automatically scans and measures the area and then records the coordinates of each scanned point. In order to obtain complete and clear point cloud data of the building's surface, a multi-station scanning was required.

Because of the fact that the point cloud data collected by the 3D laser scanner contains essentially all the objects within the scanning range, including trees, persons, etc. that are not related to the structure, post-processing needs to be performed to remove such elements that are not relevant to the study. Autodesk ReCap Pro 2020 was used for de-noising, editing, measurement and visualisation of the raw point cloud data. The field tests were designed in such a way to obtain the full details of the two structures, such as connection details, log dimensions etc.

The result of the scanning was a complex set of points called point clouds. These points show information about the field environment in grey, or in a red, green and blue (RGB) colour scale, corresponding to the intensity of the return pulse. During the scanning, the team used special labelling that reflected the location (inside or outside the structure) in order to make the post-processing more manageable.

When utilising ReCap to perform the registration process, it was not possible to achieve fully automatic merging, and a manual approach was therefore chosen to complete the process. Based on this, at least three common points in two
registration and to obtain good merging results.
and notes used in the field were taken into con
merged together. The result is shown in Figure
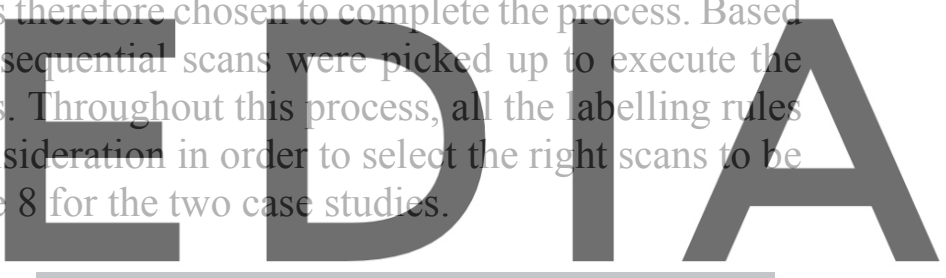

Register for free at https//www.scipedia.com to

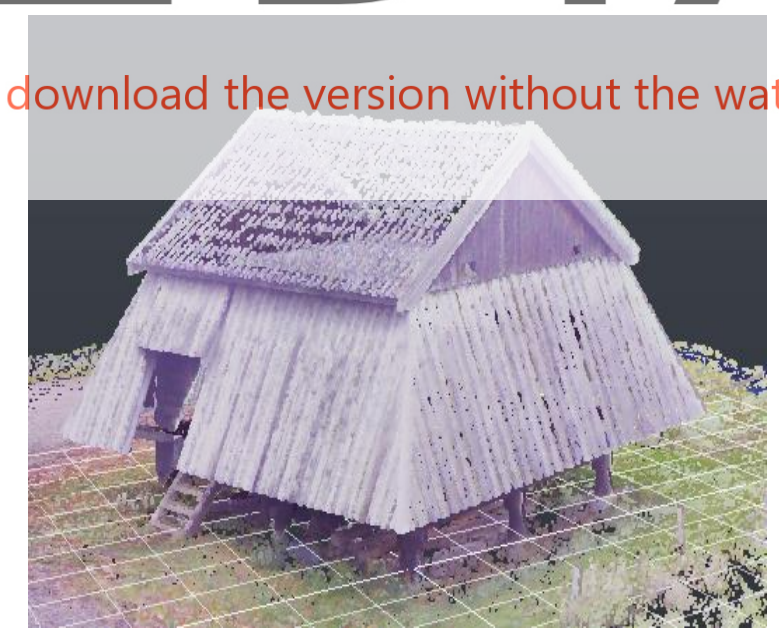

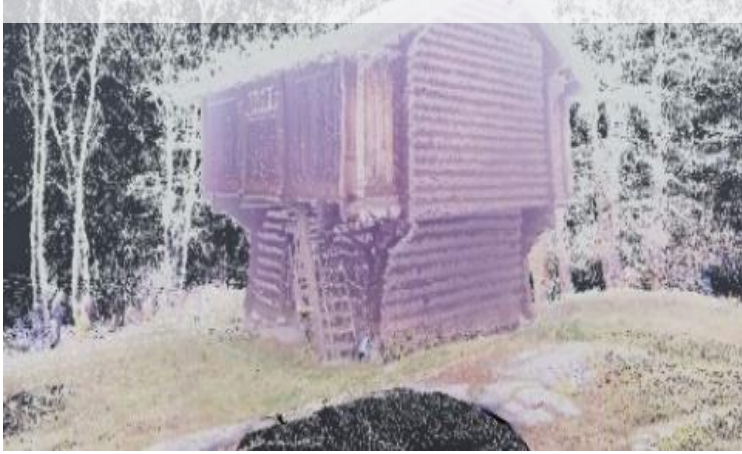

(a)

(b)

Figure 8: Raw point cloud data for (a) Heierstad Loft, (b) Fadum Storehouse

After obtaining the point clouds, the Revit building information modelling (BIM) software package was utilised to visualise the clouds based on colour intensity and elevation, and to interact within the point clouds to create an accurate building information model. As can be 
seen in Figure 9, the number of logs and their thickness have been identified and precisely depicted in the BIM file.

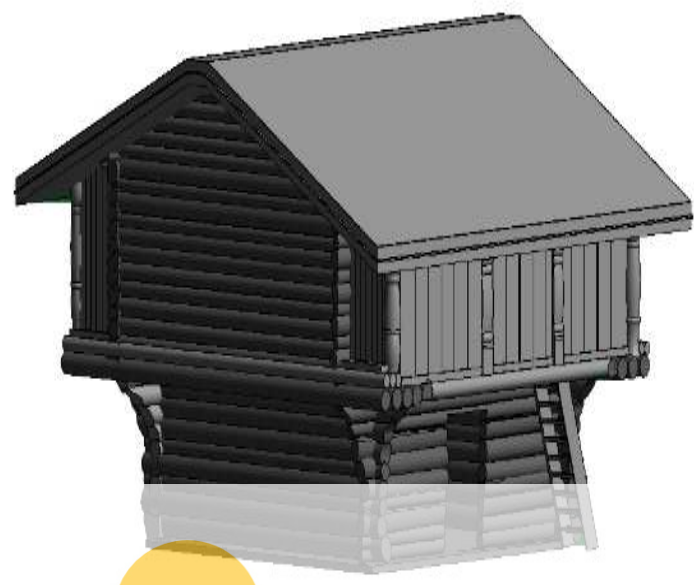

(a)

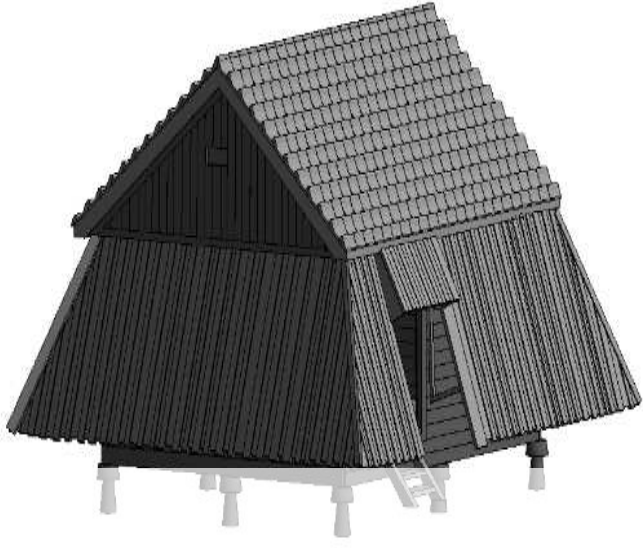

(b)

Figure 9: BIM drawing files of (a) Heierstad Loft, (b) Fadum Storehouse

For more investigation at the component scale, some parts of the buildings have been chosen in order to convert the point clouds to the surface using Geomagic design X software package.

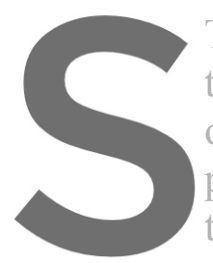
This feature of the software will be so time consuming in order to achieve the procis the structures at the component scale. Figure 10(a) and (b) show of the components and the deviation of some points from the produced from the mass point clouds. In order to timber columns in Fadum storehouse, precise nodeis have
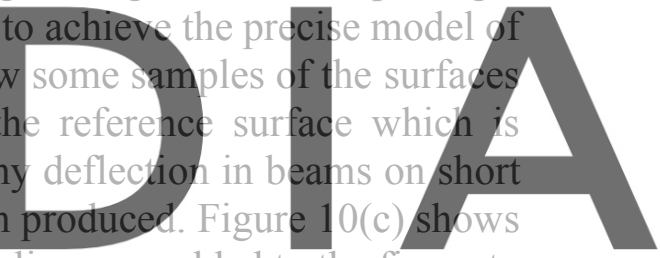
one of the beams models as a sample. Two reference horizontal lines are added to the figure to

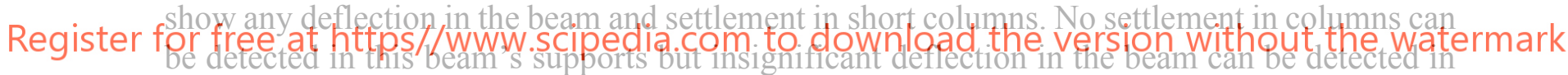
the right part of the beam. 


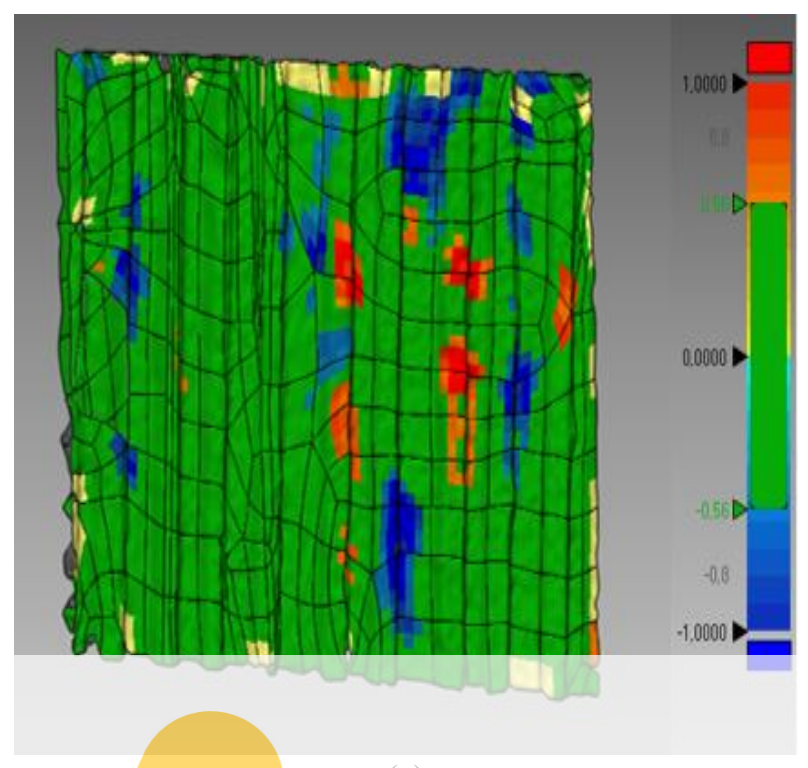

(a)

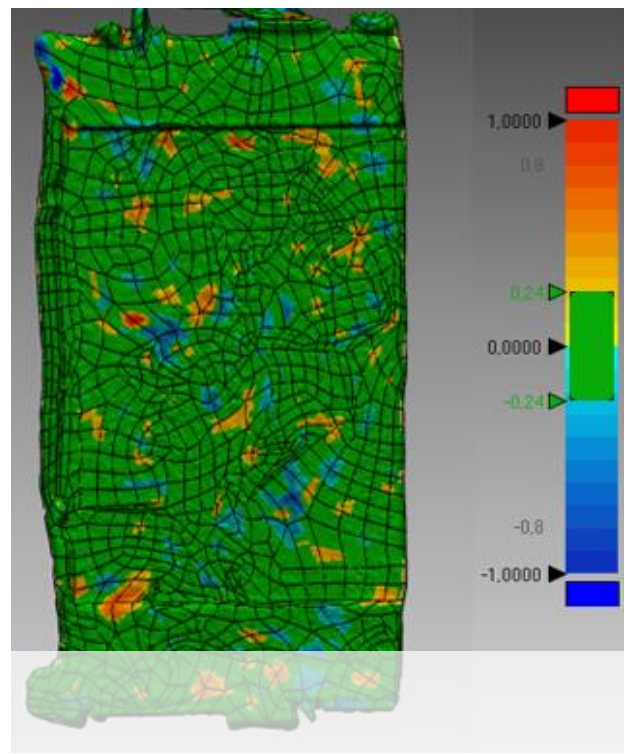

(b)

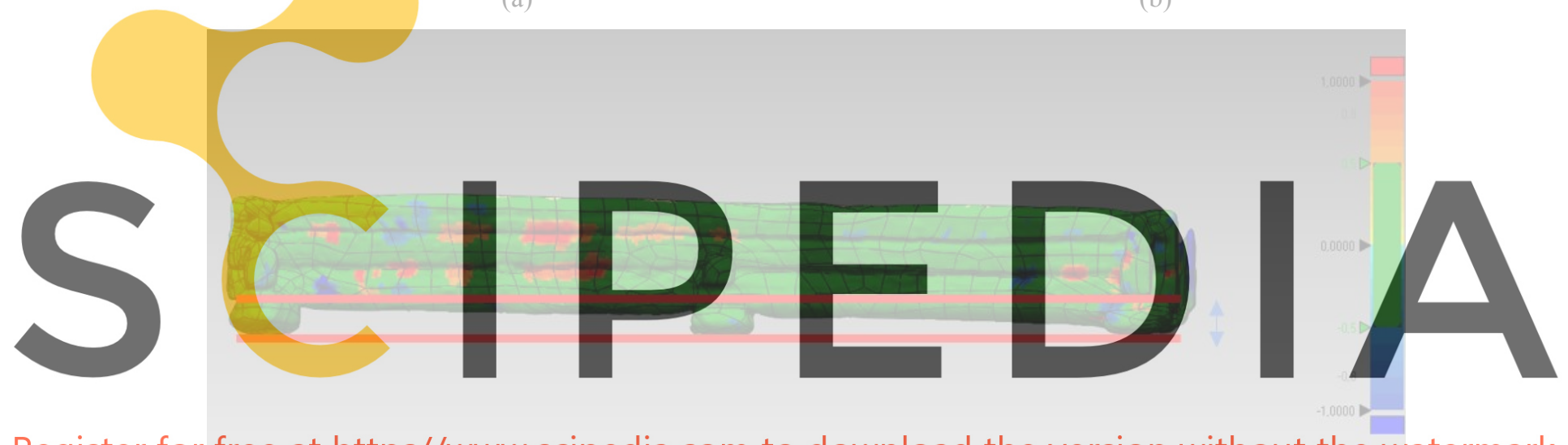
Register for free at https//www.scipedia.com to download the version without the watermark

Figure 10: (a) Surface of the coating of Fadum storehouse (see Figure 5(a)),(b) Surface of the coating of

Heierstad Loft as it was highlighted in yellow box in Figure 3(a), (c) Precise model of the beam in Fadum storehouse (see Figure 5(c)) (units in $\mathrm{mm}$ ).

In order to investigate the flatness of timber coating, Geomagic Control $\mathrm{X}$ software is utilized. Point clouds are as an input for this inspection which gives precise images of the elements and the deviation of the different parts of the element to a set of reference points. Figure 11 shows the output image of the software for one covering timber panel of the Heiersted Loft building. As it is illustrated no significant protrusion can be detected in the covering and the deviations just show the differences of the vertical timber panels' flatness. This method can be used for detecting the large cracks or delamination in timber elements' surfaces. 


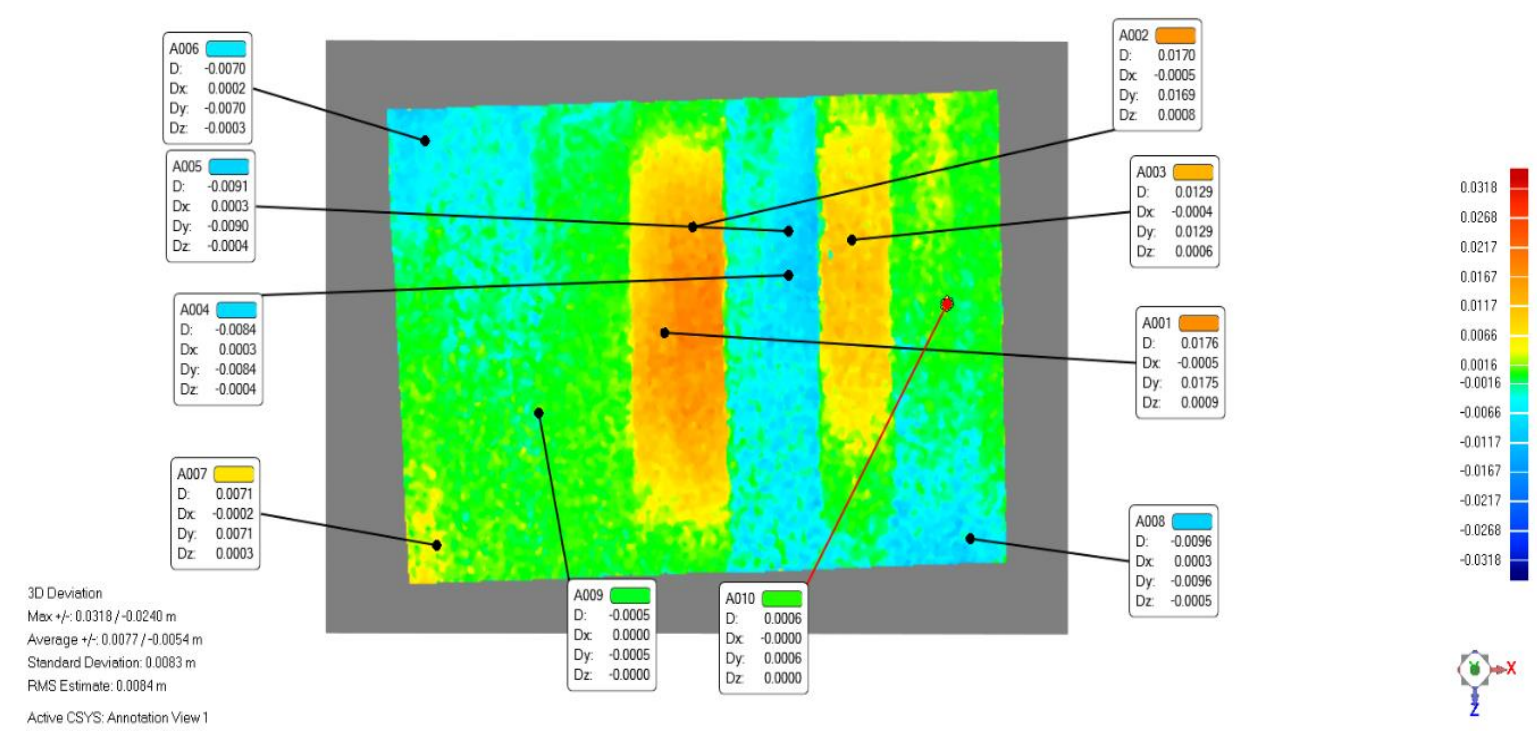

Figure 11: Covering surface of the wall of the Heierstad Loft (see Figure 3(a)) for showing any protrusion in the element (units in $\mathrm{mm}$ ).

\section{CONCLUSIONS}

- A preliminary structural survey as a fundamental step in the vulnerability assessment of heritage buildings has been performed of two log houses in Tønsberg in order to investigate their structural system, damage and future potential risks.

- $\quad$ The buildings were selected for a further geometrical survey using 3D laser scanning. 3D documentation of Heierstad Loft and Fadum Storehouse have been produced and BIM drawing files have been derived for further investigations. 3D laser scanning is much more precise than traditional 2D geometrical surveys, especially for structures with more complicated 3D geometry. The method can be effectively used for the conservation of heritage structures against potential risks.

- $\quad$ Three features of 3D laser scanners have been highlighted. Point clouds not only can be used as an input for 3D documentation of the case studies but also can be utilized in order to model precise automatically models of the components to detect any deflection or settlements in structural elements or foundations. Moreover, as the third feature of the point clouds, they can be utilized in order to find any protrusion in surfaces of the timber components which can be beneficial for detecting any cracks or delamination in surfaces.

Acknowledgements. This work is a part of the HYPERION project. HYPERION has received funding from the European Union's Framework Programme for Research and Innovation (Horizon 2020) under grant agreement no. 821054. The contents of this publication are the sole responsibility of Oslo Metropolitan University (Work Package 5, Task 2) and do not necessarily reflect the opinion of the European Union. 


\section{REFERENCES}

[1] Shabani A, Kioumarsi M and Zucconi M. State of the art of simplified analytical methods for seismic vulnerability assessment of unreinforced masonry buildings. Eng Struct (2021); 239: 112280. DOI: https://doi.org/10.1016/j.engstruct.2021.112280.

[2] Larsen KE and Marstein N. Conservation of historic timber structures. An ecological approach. Riksantikvaren, (2016).

[3] Riggio M, D'Ayala D, Parisi MA, et al. Assessment of heritage timber structures: Review of standards, guidelines and procedures. Journal of Cultural Heritage (2018); 31: 220-235.

[4] Shabani A, Kioumarsi M, Plevris V, et al. Structural Vulnerability Assessment of Heritage Timber Buildings: A Methodological Proposal. Forests (2020); 11: 881. DOI: https://doi.org/10.3390/f11080881.

[5] Cruz H, Yeomans D, Tsakanika E, et al. Guidelines for on-site assessment of historic timber structures. International Journal of Architectural Heritage (2015); 9: 277-289.

[6] Riveiro B, Morer P, Arias P, et al. Terrestrial laser scanning and limit analysis of masonry arch bridges. Construction \& Building Materials (2011a); 25: 1726-1735. DOI: https://doi.org/10.1016/j.conbuildmat.2010.11.094.

[7] Jung R-K, Koo B-S and Yu Y-S. Using Drone and Laser Scanners for As-built Building Information Model Creation of a Cultural Heritage Building. Journal of KIBIM (2019); 9: $11-20$.

[8] Milani G, Esquivel YW, Lourenço PB, et al. Characterization of the response of quasiperiodic masonry: Geometrical investigation, homogenization and application to the Guimarães castle, Portugal. Eng Struct (2013); 56: 621-641. DOI: 10.1016/j.engstruct.2013.05.040.

[9] Macchioni N, Brunetti M, Pizzo B, et al. The timber structures in the Church of the Nativity in Bethlehem: typologies and diagnosis. Journal of Cultural Heritage (2013); 13: 42-53. DOI: https://doi.org/10.1016/j.culher.2012.10.004.

[10] Pöchtrager M, Styhler-Aydın G, Döring-Williams M, et al. Digital reconstruction of historic roof structures: developing a workflow for a highly automated analysis. Virtual Archaeology Review (2018); 9: 21-33. DOI: https://doi.org/10.4995/var.2018.8855.

[11] Wilson L, Rawlinson A, Frost A, et al. 3D digital documentation for disaster management in historic buildings: Applications following fire damage at the Mackintosh building, The Glasgow School of Art. Journal of Cultural Heritage (2018); 31: 24-32. DOI: 10.1016/j.culher.2017.11.012.

[12] Degnbol H. A Dictionary of old norse prose:@Ordbog over det norrune prosasprog. Den arnamagnęanske kommission, (1989).

[13] Berg A. Norske tømmerhus frå mellomalderen, bd. II: hus for hus i Buskerud, Vestfold og Oppland. Landbruksforlaget, Oslo, (1990).

[14] Hovland JM. Kåpebur - fortidens kjøleskap eller motepåfunn? , https://www.notteroyhistorielag.no/john-m-hovland-kapebur-fortidens-kjoleskap-ellermotepafunn/ (2016, Access (2016)).

[15] Hrasnica M, Cauševic A and Rustempašić N. Laser scanning for the evaluation of historic structures. Handbook of Research on Seismic Assessment and Rehabilitation of Historic Structures. (2015), pp.734-764. 